\title{
Changes in Catecholamine-induced Lipolysis in Isolated Human Fat Cells during the First Year of Life
}

Claude Marcus, Bengt Karpe, Per Bolme, Tomas Sonnenfeld, and Peter Arner

Karolinska Institute, Departments of Pediatrics, Surgery, and Medicine, and the Research Center, Huddinge University Hospital; and

Department of Pediatric Surgery, St. Görans Hospital, Stockholm, Sweden

\begin{abstract}
Catecholamine-induced lipolysis in isolated human adipocytes during the first year of life was investigated. During this period fat cell size increased markedly. Basal and catecholamine-induced glycerol release were positively correlated with age when lipolysis was expressed per cell. However, when lipolysis was expressed per unit of cell surface area (micrometer squared), this correlation was observed only for noradrenaline. Basal lipolysis and the effect of the pure beta-agonist, isoprenaline, were identical in infants and adults. From 0 to 2 mo of age noradrenaline had very little lipolytic effect. The addition of the alpha-2-adrenoceptor antagonist, yohimbine, to noradrenaline equalized lipolysis per micrometer squared in infants and adults and the alpha-2-adrenoceptor sensitivity was significantly enhanced in infants. In both groups the lipolytic adrenoceptor was of the beta-1 type. In conclusion, adipocytes from infants have a poor lipolytic response to noradrenaline partly because of the small fat cells but mainly because of an enhanced alpha-2-adrenoceptor activity.
\end{abstract}

\section{Introduction}

Adipose tissue plays a central role as a source of energy-rich substrates in man. After the neonatal period and during the rest of the first year of life, the subcutaneous adipose tissue mass increases considerably. The average body weight increases approximately three times from birth to 1 yr of age. During that time the adipose tissue weight increases sixfold, or from 11 to $16 \%$ of the body weight, to $24-28 \%$ (1). During the 1 st year of life the adipose tissue mass expands mainly through an increase in fat cell size, although an increase in adipocyte number also takes place $(1,2)$. The factors regulating fat cell volume are unknown. Since triacylglycerols constitute $>95 \%$ of the fat cell volume, it is possible that factors which regulate the breakdown of triacylglycerols (lipolysis) are of importance for the control of fat cell size. Our knowledge of the regulation mechanism of lipolysis during infancy is poor; this is due to the difficulty in obtaining more than very small amounts of fat for in vitro studies. However, it is well established that the sympathetic nervous system, via noradrenaline and circulating catecholamines, is of significance in the regulation of lipolysis in human adults. Catecholamines and insulin are the only hormones with a pronounced acute effect on lipolysis in adult human adipocytes (3).

Address correspondence to Dr. Marcus, Department of Pediatrics, Huddinge Hospital, S-141 86 Huddinge, Sweden.

Received for publication 13 August 1986 and in revised form 23 December 1986.

J. Clin. Invest.

(c) The American Society for Clinical Investigation, Inc.

$0021-9738 / 87 / 06 / 1812 / 07 . \$ 1.00$

Volume 79, June 1987, 1812-1818
Furthermore, catecholamines, which are solely lipolytic in most species, have different effects on lipolysis in man: stimulation via beta-adrenoceptors and inhibition via alpha-2-adrenoceptors (4). The physiological meaning of dual regulation of a single metabolic pathway by a single class of hormones is not understood.

The purpose of the present investigation was to study the catecholamine regulation of lipolysis in fat cells during the 1st year of life. The effects of different adrenergic agents on lipolysis during this phase of life were evaluated by means of recently developed sensitive methods that enabled the lipolysis to be examined in detail in small human adipose samples (5).

\section{Methods}

Subjects. The study comprised 36 children aged 3 wk to 12 mo and 12 adults between 17 and 45 yr of age. It was approved by the Ethics Committee of the Karolinska Institute. Both male and female subjects were investigated. All subjects underwent elective inguinal hernia operations. None of the cases had inflamed or incarcerated hernia. They were otherwise healthy and of normal weight. The infants were arbitrarily divided into three age groups, 0-2 mo, 2-6 mo, and 6-12 mo, without any correction for gestational age. Inguinal hernias are more frequent in prematurely born infants (6), but those who were difficult to place in the abovementioned age groups were excluded.

After an overnight fast, anesthesia was induced with thiopental sodium and maintained with fentanyl and a mixture of oxygen and nitrous oxide. Pancurone was given as a muscle-relaxing agent. In some infants a $10 \%$ $\mathrm{wt} / \mathrm{vol}$ glucose solution was given intravenously during the $3 \mathrm{~h}$ before the removal of fat.

Isolation of adipocytes and determination of lipolysis. Subcutaneous adipose tissue (100-300 $\mathrm{mg}$ ) was removed from the surgical incision at the start of the operation. There was no visual evidence of fat cell necrosis or other morphological abnormalities in the area of the fat biopsy. Fat cells were isolated by collagenase digestion using Rodbell's method (7). The adipocytes were incubated in duplicate for $2 \mathrm{~h}$ at $37^{\circ} \mathrm{C}$ in Kreb'sRinger phosphate buffer ( $\mathrm{pH} 7.4)$ containing albumin ( $40 \mathrm{~g} /$ liter), glucose ( $1 \mathrm{~g} /$ liter), and ascorbic acid $(0.1 \mathrm{~g} /$ liter $)$, with air as the gas phase. The final fat cell concentration was $1 \% \mathrm{vol} / \mathrm{vol}$, which corresponded to $\sim 5,000-10,000$ cells $/ \mathrm{ml}$. At the end of the incubation, an aliquot of the medium was removed for the analysis of glycerol release, which was used as an index of lipolysis and was determined by a kinetic bioluminescence method (5). Fat cell diameter was measured (8). Mean fat cell volume and fat cell surface area were calculated. The formula used to calculate the fat cell surface area was (mean diameter of the fat cell ${ }^{2}$ + the standard deviation of the diameter $\left.{ }^{2}\right) \times \pi$. The theoretical background to the formulas used has been discussed in detail previously $(9,10)$.

Lipolysis in segments of adipose tissue. In some methodological experiments lipolysis was investigated in fat fragments. Adipose tissue was cut into pieces each weighing $10-20 \mathrm{mg}$. About $20 \mathrm{mg}$ of tissue was incubated in $1 \mathrm{ml}$ of medium as described above.

Expressions of the results. Lipolysis was expressed per cell or per unit of cell surface area. The maximal beta-agonist-induced lipolysis (responsiveness) was calculated from each individual dose-response curve as the difference between basal glycerol release and glycerol release at 
the maximum effective agonist concentration. The concentration of agonist that produced $50 \%$ of the maximum effect $\left(E_{50}\right)$ was calculated graphically from the individual dose-response curves.

Chemicals. Noradrenaline, adrenaline, isoprenaline, clonidine, propranolol, and yohimbine were obtained from Sigma Chemical Co., St. Louis, MO. The collagenase was prepared from clostridium histolyticum and was of Sigma type 1. Dialyzed bovine serum albumin (fraction V) was purchased from the Armour Pharmaceutical Co., Eastbourne, England. The same batch was used in all experiments. All other chemicals were of the highest purity grade commercially available.

Statistical methods. The values presented are the means and the standard error of the mean (SE). The statistical methods used were Student's unpaired $t$ test and linear regression analysis.

\section{Results}

Age, sex, and fat cell size. Age and fat cell size in the groups studied are shown in Table I. There was a positive correlation between the age of the subjects and fat cell size during the first year of life $(r=0.685, P<0.001)$, but no such correlation in the group of adult subjects $(r=0.014)$. The increase in fat cell volume was most pronounced during the first 6 mo $(2.5$-fold increase in cell volume). The further increase in cell volume from the 6-12-mo-old infants to the adults was less marked (1.5-fold), but the difference was significant $(P<0.05)$. Approximately $10 \%$ of the subjects investigated were female; however, we found no difference in lipolysis between males and females.

Basal lipolysis. The basal (unstimulated) lipolysis in fat cells from the different age groups studied is shown in Table II. Expressed per cell there was an increase in lipolysis with increasing age $(r=0.58, P<0.001)$. However, when basal lipolysis was expressed per unit of cell surface area there was no such correlation with age $(r=0.067)$, and the basal lipolytic rates were similar in all the groups. Furthermore, fat cell volume correlated significantly with lipolysis per cell $(r=0.75, P<0.001)$, but not with lipolysis per cell surface area.

Lipolytic effect of catecholamines. The effects of the pure beta-agonist isoprenaline and the combined alpha- and betaagonist noradrenaline on lipolysis in the four age groups are shown in Fig. 1. In all groups the lipolytic response to isoprenaline expressed per cell was significant and dose dependent (Fig. $1 \mathrm{~A}$ ). A positive influence of age was observed at all isoprenaline concentrations, and the maximum lipolytic effect showed a positive correlation with age $(r=0.60)$. However, when isoprenalineinduced lipolysis was expressed per unit of cell surface area, the dose-response curves were almost identical in the different age groups. Thus, there was no significant difference in the response at any concentration of the drug (Fig. $1 C$ ). Isoprenaline sensi-

Table I. Characteristics of the Age Groups

\begin{tabular}{lcccc}
\hline & $0-2 \mathrm{mo}$ & $2-6 \mathrm{mo}$ & $6-12 \mathrm{mo}$ & Adults \\
\hline (M/F) & $9 / 1$ & $10 / 1$ & $8 / 1$ & $7 / 3$ \\
Age & $6 \pm 2 \mathrm{wk}$ & $13 \pm 4 \mathrm{wk}$ & $39 \pm 10 \mathrm{wk}$ & $31 \pm 7 \mathrm{yr}$ \\
$\begin{array}{l}\text { Adipocyte } \\
\quad \text { volume }(p l)\end{array}$ & $134 \pm 50$ & $200 \pm 93$ & $329 \pm 100$ & $497 \pm 168$
\end{tabular}

The subjects were divided into four age groups: infants $\leq 2 \mathrm{mo}$, infants $>2 \mathrm{mo}$ and $\leq 6 \mathrm{mo}$, infants $>6 \mathrm{mo}$ and $\leq 12 \mathrm{mo}$, and adults. Values are means $\pm \mathrm{SD}$. M, male; F, female.
Table II. Basal Lipolysis Rate in Infants and Adults

\begin{tabular}{llllll}
\hline & \multicolumn{2}{l}{ Glycerol release } & & $\begin{array}{c}\text { Correlation } \\
\text { between age } \\
\text { and lipolysis }\end{array}$ \\
\cline { 2 - 6 } & $0-2 \mathrm{mo}$ & $2-6 \mathrm{mo}$ & $6-12 \mathrm{mo}$ & Adults & \\
\hline$\mu \mathrm{mol} \mathrm{per}$ \\
$\begin{array}{l}\mu \mathrm{m}^{2} \mathrm{per} \\
2 \mathrm{~h} \times 10^{-11}\end{array}$ & $1.3 \pm 0.2$ & $1.0 \pm 0.3$ & $1.5 \pm 0.3$ & $1.2 \pm 0.2$ & $r=0.067$ \\
$\begin{array}{c}\mu \mathrm{mol} \mathrm{per} \\
10^{7} \mathrm{cells} \\
\text { per } 2 \mathrm{~h}\end{array}$ & $1.6 \pm 0.2$ & $1.8 \pm 0.5$ & $3.2 \pm 0.6$ & $3.6 \pm 0.6$ & $r=0.58$ \\
\hline
\end{tabular}

The age groups are the same as in Table I. Lipolysis was expressed per cell surface area or per cell. The correlation between basal glycerol release and age was examined in the whole material, using linear regression analysis.

tivity was not age dependent. The $\mathrm{ED}_{50}$ was obtained at $\sim 1$ $\mathrm{nmol} /$ liter of isoprenaline in all groups.

The lipolytic effect of noradrenaline was poor in the youngest group of infants, with a mean maximal response of $80 \%$ over the basal values. The response increased gradually in the older infants and reached adult levels $(\sim 2$.5-fold stimulation of basal lipolysis) in the 6-12-mo age group. However, contrary to what was found concerning unstimulated and isoprenaline-induced lipolysis, the noradrenaline-induced lipolysis showed a persistent age dependency whether it was expressed per unit of cell surface area or per fat cell (Fig. 1, $B$ and $D$ ). There was also a positive correlation between age and the individual maximal lipolytic response to noradrenaline in the entire infant group $(r=0.605)$, but not in the adult group $(r=0.167)$, when it was expressed per cell surface area.

The sensitivity of the cells to noradrenaline, expressed as $E_{50}$, did not vary significantly between the age groups. The $\mathrm{ED}_{50}$ value indicated for the youngest group is, nevertheless, uncertain, since the poor lipolytic response in this group causes considerable errors in the $\mathrm{ED}_{50}$ values for noradrenaline.

Effect of yohimbine on catecholamine-induced lipolysis. The lipolytic response of noradrenaline was lower than that of isoprenaline in human adults, since the catecholamines activate both the lipolytic beta-adrenoceptors and the antilipolytic alpha2-adrenoceptors (4). The difference in lipolysis between age groups shown in Fig. 1 seems to be due partly to the well-known fact that there is a positive correlation between fat cell size and lipolysis when the metabolic rate is expressed per cell (10). Conversely, factors unrelated to fat cell size may also be involved. To investigate whether the poor lipolytic effect of noradrenaline in early infancy, which persisted when compensation was made for the differences in fat cell size (Fig. $1 D$ ), was due to enhanced alpha-2-adrenoceptor-mediated activity, the effect of the addition of yohimbine (selective alpha-2-antagonist) was studied in two subgroups of the material: six infants 1-4 mo of age and six adults (Fig. 2). The yohimbine concentration used $\left(10^{-4} \mathrm{~mol} /\right.$ liter) was chosen to give a complete blockade of the alpha-2adrenoceptors (11). Without yohimbine the noradrenaline-induced lipolysis in the infant group was in the same range as in the 2-6-mo-old group shown in Fig. $1-$ i.e., $\sim 50 \%$ of the response in the adult group. With yohimbine added to the medium, the differences between the age groups disappeared and the lipolytic response of noradrenaline increased to the same range as that shown in Fig. 1 for isoprenaline. In uncharted experiments yohimbine had the same effect on adrenaline-induced lipolysis 
A

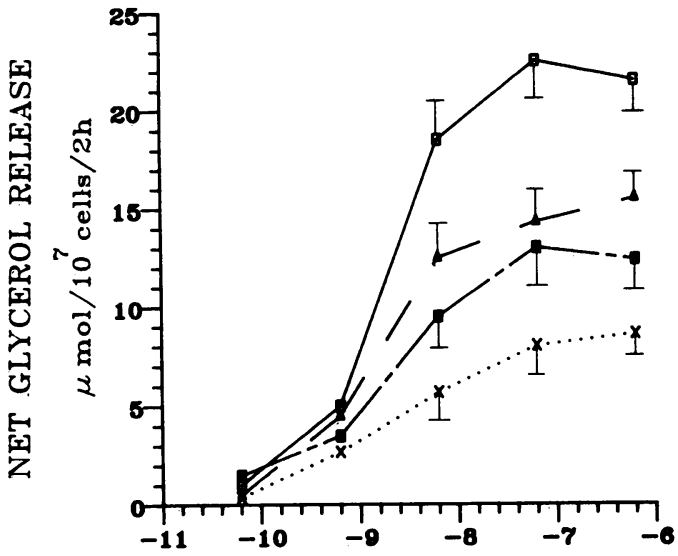

B

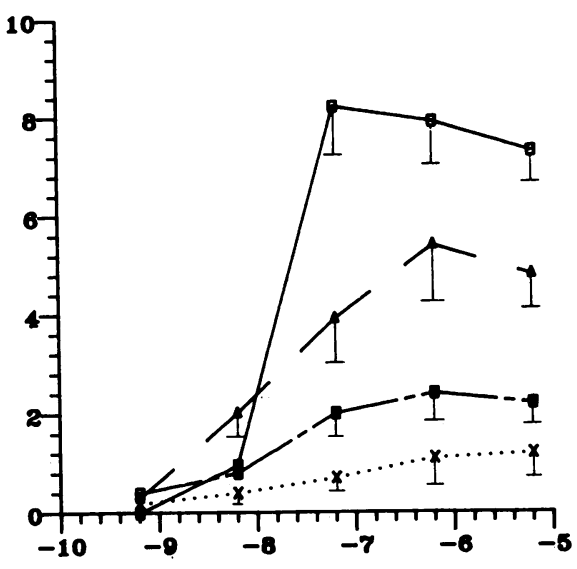

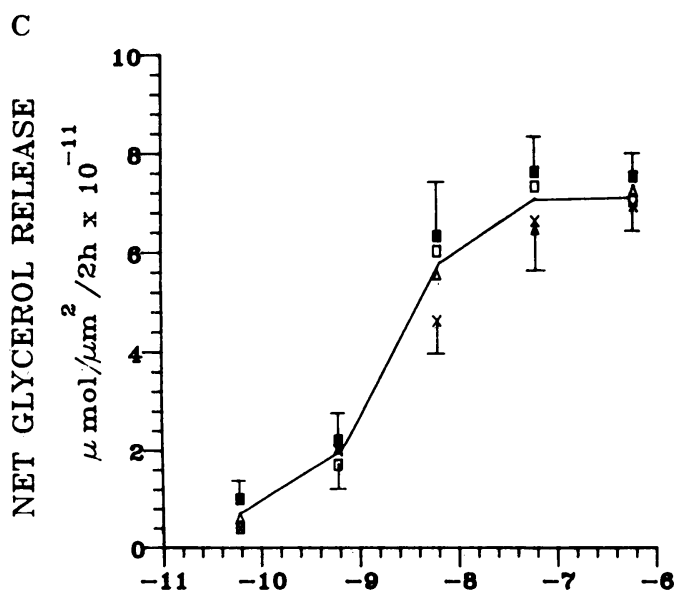

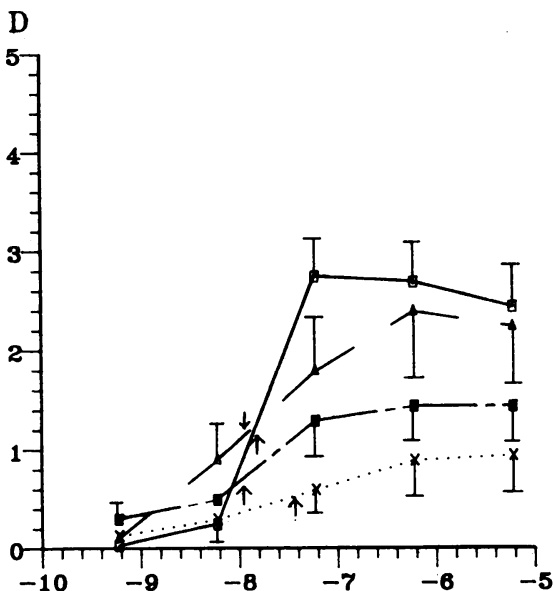

Figure 1. Isoprenaline- and noradrenaline-induced lipolysis during the first year of life and at adult age. Adipocytes were incubated with increasing concentrations of noradrenaline and isoprenaline. The glycerol release to the medium was determined. $\mathrm{Li}$ polysis is expressed per cell in $A$ and $B$, and per unit of cell surface area in $C$ and $D$. ED 50 of noradrenaline are indicated with arrows in $D$. The $E_{50}$ of isoprenaline was $1.3 \pm 0.7 \mathrm{nmol} /$ liter. The basal glycerol release was subtracted from the catecholamine-induced values so that net glycerol release is given. The values are mean \pm SE. $(x)$ 0-2 mo; (๑) 2-6 mo; ( $\triangle$ ) 6-12 mo; and (口) LOG DRUG CONCENTRATION, MOL/L adults.

as it had on noradrenaline-induced lipolysis in the two groups. Yohimbine alone had no effect on lipolysis (data not shown). Since the difference between maximal lipolytic responses to noradrenaline and isoprenaline was due to alpha-2-adrenoceptormediated inhibition both in infants and adults, the percent alpha2 reduction in noradrenaline-induced lipolysis can be calculated as isoprenaline minus noradrenaline divided by isoprenaline in each subject. This value for alpha-2 inhibition, which is not dependent on the expression of lipolysis (per cell or surface area), was $84 \pm 12 \%$ in the youngest infant group (0-2 mo) compared with $50 \pm 16 \%$ in the adult group.

The lipolytic potency of isoprenaline, noradrenaline, and adrenaline together with yohimbine (expressed as a percentage of the maximal effect to avoid the influence of cell size on lipolysis) is shown in Fig. 3. With yohimbrine in the medium acting as an alpha-2-adrenoceptor blocker, the catecholamines interact almost exclusively with beta-adrenoceptors. The relative order of potency between isoprenaline and the catecholamines was: isoprenaline $>$ noradrenaline $=$ adrenaline, both in infants and adults. These results are in agreement with the classical pharmacological definition of the beta-1-adrenoceptor both in infants and adults.

Antilipolytic effect of catecholamines. The antilipolytic effect of catecholamines was investigated in two ways: by studying the

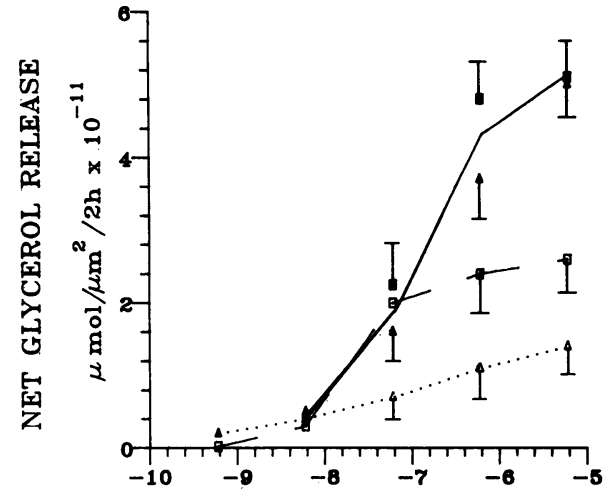

\section{NORADRENAIINE CONCENTRATION}

$\log \mathrm{mol} / \mathrm{l}$

Figure 2. Effect of yohimbine on noradrenaline-induced lipolysis. ( $A$ and $C$ ) Isoprenaline; $(B$ and $D)$ noradrenaline. Isolated fat cells from six infants 0-4 mo (triangles) and six adults (squares) were incubated with indicated concentrations of noradrenaline alone (open symbols) or with the addition of $10^{-4} \mathrm{~mol} / \mathrm{liter}$ yohimbine (filled symbols). The characteristics of the age groups were $(a)$ infants, five males and one female, age $9 \pm 3 \mathrm{wk}$, fat cell volume $180 \pm 86 \mathrm{pl}$; and $(b)$ adults, six males, age $31 \pm 7 \mathrm{yr}$, fat cell volume $497 \pm 168 \mathrm{pl}$. 


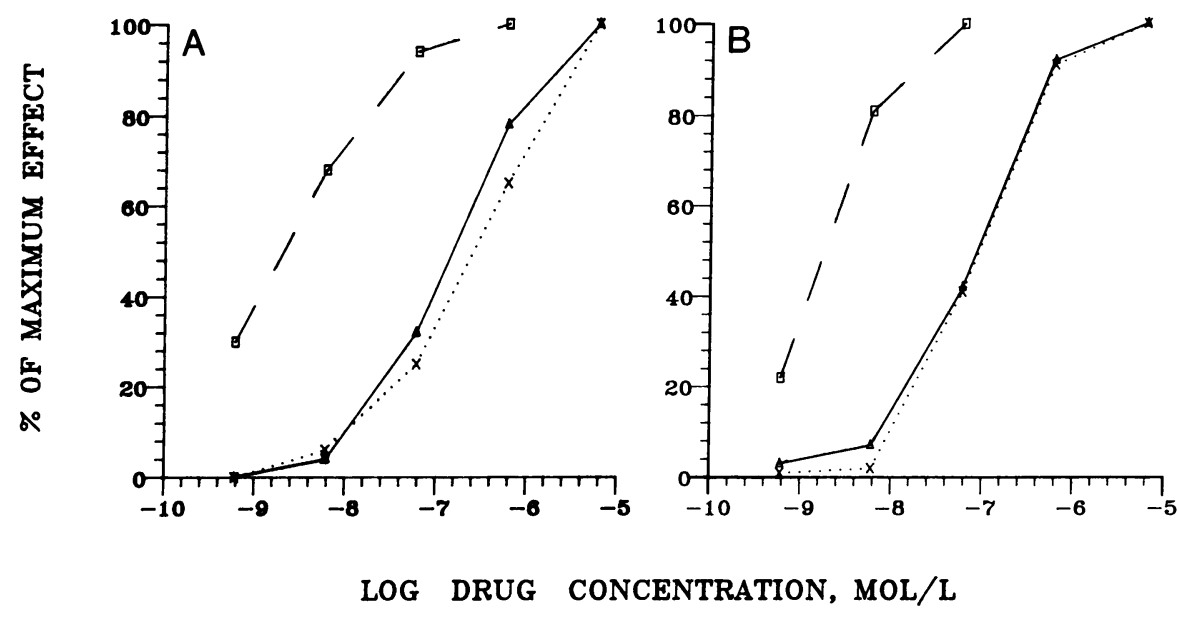

Figure 3. Sensitivity of catecholamineinduced lipolysis. $(A)$ 0-4 mo; $(B)$ adults. The relative order of potency of $(\square)$ isoprenaline, $(\Delta, \Delta)$ adrenaline, and $(x)$ noradrenaline induced lipolysis in fat cells obtained from infants and adults. Fat cells were obtained from the same subjects as in Fig. 2 and incubated with or without increasing concentrations of catecholamines. Yohimbine $\left(10^{-4} \mathrm{~mol} / \mathrm{liter}\right)$ was added to the medium to block the alpha-2-adrenoceptormediated antilipolytic effect of the catecholamines. Lipolysis is expressed here as a percentage of the maximal lipolytic effect of each catecholamine. The individual $\mathrm{ED}_{50}$ values, calculated as described in Methods, were also determined: isoprenaline, infants $1.7 \pm 0.7 \mathrm{nmol} / \mathrm{liter}$ and adults $1.2 \pm 0.4$

$\mathrm{nmol} / \mathrm{liter}$; adrenaline, infants $215 \pm 85 \mathrm{nmol} / \mathrm{liter}$ and adults $85 \pm 38 \mathrm{nmol} / \mathrm{liter}$; and noradrenaline, infants $412 \pm 255 \mathrm{nmol} /$ liter and adults $88 \pm 32$ nmol/liter.

antilipolytic effect of the combined alpha- and beta-agonists, noradrenaline and adrenaline, during beta-adrenoceptor blockade (12), and by means of the synthetic selective alpha-2-adrenoceptor agonist, clonidine. Theophyllamine was added to the incubation medium as a lipolytic agent, as suggested previously (12). Propranolol was added to noradrenaline and adrenaline at a concentration $\left(10^{-4} \mathrm{~mol} / \mathrm{liter}\right)$, which gives a complete betaadrenoceptor blockade (13). When propranolol was added alone to the fat cells it had no effect on lipolysis (data not shown). Infants aged 0-4 mo and adults were investigated.

Fig. 4 shows the maximal inhibitory effect of noradrenaline, adrenaline, and clonidine on lipolysis induced with theophyllamine $\left(10^{-3} \mathrm{~mol} /\right.$ liter $)$. There were no significant differences in maximum inhibition of lipolysis either between the drugs or between the age groups when glycerol release was expressed per cell surface area. Furthermore, the theophyllamine-induced li-

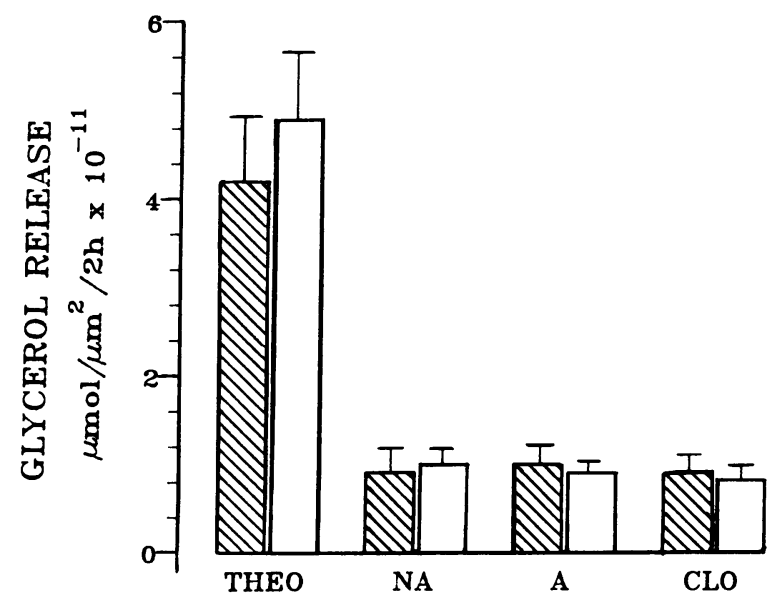

Figure 4. Antilipolytic effect of noradrenaline, adrenaline, and clonidine. Adipocytes from six infants and six adults (open bars) were incubated with increasing concentrations of noradrenaline (NA), adrenaline (A), and clonidine (CLO) with theophyllamine (THEO, $10^{-3} \mathrm{~mol} /$ liter) as lipolytic agent. Propranolol $\left(10^{-4} \mathrm{~mol} / \mathrm{liter}\right)$ was used to block the beta-adrenoceptor activity of NA and A. Glycerol release in the absence or in the presence of maximum effective concentrations of the various antilipolytic agents is given. The same infants as in Fig. 2 were investigated. polysis in the absence of inhibiting agent was not significantly different statistically in infants and adults.

For the study of the sensitivity of the drugs, the dose-response curves were plotted as percent of maximal effect to avoid the influence of the expression of the rate of lipolysis (per cell or surface area). These results are given in Fig. 5. All the doseresponse curves were shifted to the left in the infant group as compared with the adults. To evaluate statistically the differences in sensitivity between the groups, $\mathrm{ED}_{50}$ for each individual doseresponse curve was determined. The means of the $\mathrm{ED}_{50}$ values were significantly lower for noradrenaline, adrenaline, and clonidine in infants as compared with adults (Table III).

In theory, the initial rates of lipolysis may influence the shape of the dose-response curves of antilipolytic drugs. Therefore it was of importance to exclude the possibility that small variations in the lipolytic effect of theophyllamine between infants and adults had a major influence on the $\mathrm{ED}_{50}$ values. Using the data in Table IV, we compared the three infants who had the highest lipolytic effects of theophyllamine with the three adults who had the lowest lipolytic effects of theophyllamine. The difference in $E_{50}$ values for all catecholamines between infants and adults persisted in these extreme subgroups (values not shown). Thus, small differences in theophyllamine-induced lipolysis between infants and adults have no bearing on the results with catecholamine sensitivity.

Effects of adenosine deaminase on lipolysis. The effects of 1 $\mathrm{U} / \mathrm{ml}$ of adenosine deaminase (ADA), ${ }^{1}$ which inactivates endogenous adenosine, was examined in fat cells of three children of $0-4$ mo of age. The cells were incubated with or without different concentrations of noradrenaline. Lipolysis was expressed as micromoles of glycerol per $2 \mathrm{~h}$ per $\mu \mathrm{m}^{2} \times 10^{-11}$. ADA increased the basal lipolytic rate from $1.3 \pm 0.4$ to $2.2 \pm 0.6$. However, it did not alter the maximal lipolytic response of noradrenaline (1.7 \pm 0.7 without ADA and $1.6 \pm 0.7$ with ADA). Likewise, ADA had no effect on noradrenaline-induced lipolysis in fat cells of adult subjects (data not shown).

Effect of collagenase incubation of adipose tissue. It is reported that the adipocyte isolation process with collagenase has effects on lipolysis in human adults (14). Catecholamine-induced

1. Abbreviation used in this paper: ADA, adenosine deaminase. 

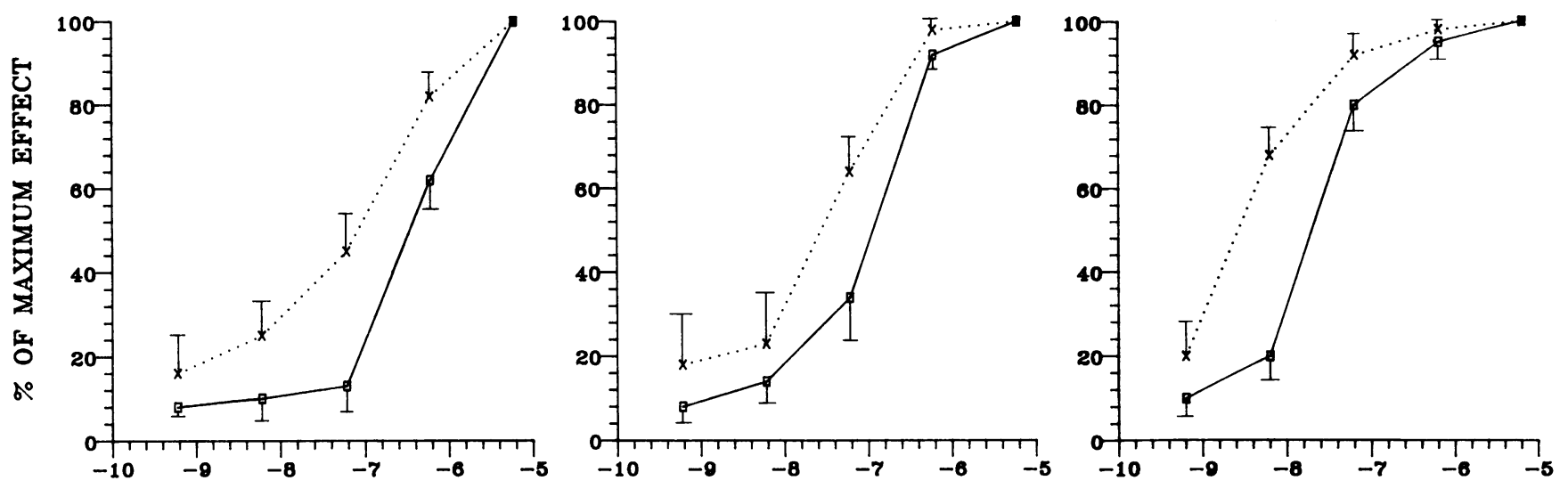

\section{LOG DRUG CONCENTRATION, MOL $/ 1$}

Figure 5. Sensitivity of the catecholamine- and clonidine-induced antilipolysis. The dose-response curves for (left) noradrenaline, (middle) adrenaline, and (right) clonidine from the investigation in Fig. 4 were plotted as a percentage of the maximal inhibitory effect. The latter was

lipolysis is increased in isolated fat cells as compared with fat segments, and this is due to inhibition of phosphodiesterase by collagenase. In theory, infant adipose tissue may respond differently from adult tissue to collagenase. Therefore, the lipolytic effects of catecholamines in isolated adipocytes were compared with those in fragments of adipose tissue from two 2-3-mo-old infants. The fragments had the same basal lipolysis as the isolated cells. Noradrenaline stimulated basal lipolysis $14 \%$ in fragments and $91 \%$ in isolated cells. Isoprenaline stimulated basal lipolysis 5.6-fold in fragments and 7.8-fold in cells. Thus, the lipolytic effect of catecholamines is increased in isolated infant adipocytes as it is in isolated adult cells.

Effect of glucose infusion on lipolysis. Infants have in general a higher metabolic turnover than adults. To determine whether the fasting period had any influence on the lipolytic rate, we gave infants 2-4 mo of age glucose infusions during the $3 \mathrm{~h}$ before the start of the operation. However, there were no differences in basal, maximal noradrenaline, or maximal isoprenaline-induced lipolysis in fat cells obtained from these infants compared with age- and weight-matched infants who did not receive glucose infusions before the operation (Table IV).

\section{Discussion}

In the present study the effect of catecholamines on lipolysis during the 1st year of life has been investigated for the first time

Table III. Concentration of Drugs Giving

Half-Maximum Inhibition of Lipolysis $\left(E D_{s a}\right)$

\begin{tabular}{lllr}
\hline & & & \\
\cline { 2 - 4 } $\begin{array}{l}\text { Study } \\
\text { group }\end{array}$ & Noradrenaline & Adrenaline & Clonidine \\
\hline Infants & $64 \pm 18$ & $30 \pm 12$ & $3 \pm 1$ \\
Adults & $440 \pm 185$ & $156 \pm 42$ & $23 \pm 4$ \\
$P$ & $<0.01$ & $<0.05$ & $<0.01$ \\
\hline
\end{tabular}

The experiments in Fig. 5 were used to calculate $E_{s 0}$ from each doseresponse curve. The statistical difference was tested using Student's unpaired $t$ test. calculated as glycerol release with only theophyllamine and propranolol present in the medium, minus glycerol release at the maximum effective inhibitory concentration of the hormone. The same infants aged 0-4 mo $(x)$ and adults $(\square)$ as in Fig. 2 were investigated.

in some detail. It was observed that the adipocyte size increased markedly during this period of life. This is in accordance with what has previously been shown by others $(1,2)$, although some authors (15) have found divergent results with only a slight increase in fat cell size during this period. The reason for this discrepancy is unclear. In the latter paper, all the ages were adjusted for gestational age. This could, perhaps together with methodological variations in the estimates of fat cell size (16), explain the differences in results.

Of greater importance, however, is the marked age dependency of lipolysis. This age dependency had two different characteristics. First, basal and catecholamine-induced lipolysis increased gradually during the 1st year, when lipolysis was expressed per cell number. This correlated significantly with the increase in fat cell size during the 1st year of life, which confirms the well-known observation that lipolysis per cell is related to the size of the adipocyte (10). This is not a surprising finding, since it seems physiological that a large cell has a more marked metabolic activity than a small one. The dual effects of catecholamines on lipolysis in human fat cells, stimulation via betaadrenoceptors and inhibition via alpha-adrenoceptors, have been known for a long time $(17,18)$. However, the increase in lipolysis per cell during the 1 st year of life is probably not mainly due to

Table IV. Effect of Glucose Infusion on Lipolysis in Infants

\begin{tabular}{llcl}
\hline & \multicolumn{3}{l}{ Glycerol release $\left(\mu \mathrm{mol} / \mathrm{nm}^{2}\right.$ per $\left.2 \mathrm{~h} \times 10^{-11}\right)$} \\
\cline { 2 - 4 } Group & Basal & Noradrenaline & Isoprenaline \\
\hline Glucose & $\begin{array}{c}0.9 ; 0.8 \\
(\text { mean } 0.9)\end{array}$ & $\begin{array}{c}1.2 ; 1.8 \\
(\text { mean } 1.5)\end{array}$ & $\begin{array}{c}7.4 ; 5.2 \\
(\text { mean 6.3) }\end{array}$ \\
Fasted & $1.0 \pm 0.3$ & $1.5 \pm 0.6$ & $6.5 \pm 1.1$
\end{tabular}

Two infants ( $2 \mathrm{mo}, 4 \mathrm{mo}$ ) received $10 \% \mathrm{wt} / \mathrm{vol}$ glucose solution $(3 \mathrm{ml} /$ $\mathrm{kg}$ body wt per $\mathrm{h}$ ) during the $3 \mathrm{~h}$ before removal of fat. Fat cells were incubated with or without various concentrations of noradrenaline or isoprenaline. Glycerol release at maximum effective catecholamine concentration is given. The results (mean $\pm \mathrm{SE}$ ) in 10 children aged 2-4 mo who were fasted overnight are given for comparison. 
altered adrenoceptor activity. The effect of isoprenaline (pure beta-agonist), as well as that of noradrenaline (combined alphaand beta-agonist), increased markedly during this period. In the first place, the properties of the lipolytic beta-adrenoceptor seemed to be unchanged during this period. Catecholamine-induced lipolysis in adults is mainly mediated via beta-1-adrenoceptors (19), and the relative order of potency in the lipolytic effects of isoprenaline, noradrenaline, and adrenaline during alpha-2-blockade in the present study was similar in infants and adults. This suggests that the beta-1-adrenoceptor activity is also predominant during infancy. Secondly, isoprenaline sensitivity was similar in infants and adults. Finally, both basal and catecholamine-induced lipolysis increased markedly with age. The increase in the rate of catecholamine-induced lipolysis during infancy seems to be at least partly due to the increase in fat cell size and thus not only to altered physiological properties in the cells.

Conversely, marked differences between the various lipolytic activities were observed during the 1st year of life when lipolysis was related to fat cell surface area. With this expression of lipolysis both the basal and the isoprenaline-stimulated rates were almost identical in infants and adults. However, a marked age dependency was observed with the endogenous catecholamine noradrenaline. The lipolytic effect of the hormone was very poor in isolated fat cells from infants below 2 mo of age, but it gradually increased in infants up to 6-12 mo of age, when it reached almost the same levels as in adults. This difference in noradrenaline effect between infants and adults could hardly be explained by an alteration in the beta-adrenoceptor activity. The results of methodological experiments indicate that it is not due to different sensitivities to collagease treatment between infant and adult fat cells. Instead, our data clearly indicate that the decreased noradrenaline effect in infants, which thus persisted whether lipolysis was expressed per unit of cell surface area or per cell, was mainly due to alterations in the effect mediated via the alpha2-adrenoceptors. There is much evidence for this assumption. First, the differences in the lipolytic effects of noradrenaline between the age groups disappeared completely when the alpha-2 blocking agent, yohimbine, was present in the medium. Secondly, in the infant group there was an increased sensitivity to both natural catecholamines and the synthetic selective alpha2-adrenoceptor against, clonidine, with regard to the antilipolytic activity. Thirdly, the noradrenaline/isoprenaline quotient (which represents alpha-adrenoceptor activity) was enhanced in infancy.

The enhanced alpha-2-adrenoceptor-mediated antilipolytic effect in the youngest age group may have several explanations. It may be due to a modulation of the binding of the catecholamines to the alpha-2-adrenoceptor-i.e., alterations in receptor number or affinity. It may also be due to changes beyond the receptor level, such as in the interaction between the receptor and the GTP-sensitive inhibitory coupling protein, or in the interaction between the coupling protein and the catalytic component of adenylate cyclase. Unfortunately, it is not at present possible to clarify these questions. The study of catecholamine binding, of coupling proteins, and of adenylate cyclase in fat cells requires much larger amounts of adipose tissue than, for ethical reasons, it is possible to remove from infants. However, the observed alteration in the alpha-2-adrenergic sensitivity indicates that changes in or near the alpha-2-adrenoceptor may be of importance.

It has recently been suggested that adenosine, which acts as a paracrine modulator of the cyclic AMP-system, is one of the factors responsible for the poor lipolytic effect of catecholamines in the adipose tissue of obese adult subjects during caloric restriction (20). The poor effect of noradrenaline during infancy is probably not due to variations in the endogenous adenosine levels. The addition of ADA, which effectively breaks down adenosine to inosine, did not alter the catecholamine-induced lipolysis either in the infants or in the adult group.

In this study adipose tissue was obtained after an overnight fast, and it is well known that catecholamine-induced lipolysis can be modulated by prolonged fasting in man (3). In theory, infant fat cells may be more sensitive in this respect than adult adipocytes. However, for several reasons this seems not to be of importance for the present results. First, the increase in the basal rate of lipolysis is the principal finding during fasting (3), and this was not observed in infants. Secondly, the results with glucose infusion did not differ from those observed with overnight fasting.

Little is known about the regulation of lipolysis during infancy. In the few studies published so far the methods used to determine lipolysis have proved insensitive and only a small number of subjects have been studied $(21,22)$. Novak et al. (23) reported that the adipose tissue of newborn infants is less sensitive to catecholamines than is adipose tissue from old persons. It is also of interest that both free fatty acids and glycerol are reported to be very low at the time of birth $(24,25)$, although the catecholamine concentration has been reported to be high in blood samples from the fetal scalp during delivery and from the umbilical cord $(26,27)$. A poor correlation between umbilical cord concentrations of catecholamines and glycerol is also reported $(26,28)$. It has to be emphasized that the results in this study were obtained during in vitro conditions that cannot be directly extrapolated to in vivo situations. Furthermore, the present study did not directly concern the neonatal period. Nevertheless, it seems reasonable to believe that the increase in the alpha-2adrenoceptor inhibition of lipolysis is one factor behind the impaired effect of catecholamines during delivery and after birth. It may also be viewed as a physiologically protective mechanism against excessive lipid mobilization in situations with a high catecholamine secretion.

The enhancement of alpha-2-adrenoceptor activity in fat cells during infancy may also be of physiological importance for the growth of fat cells during this period of life. Inhibition of the lipolytic effect of catecholamines protects the fat cell from exhaustion of its lipid stores and thereby favors an expansion of the fat cell volume. Thus, the enhanced alpha-2-adrenoceptor activity may be partly responsible for the rapid increase in fat cell size observed during the first 6 mo of life.

In summary, we have found that noradrenaline during the first months of life has a very limited lipolytic effect in vitro owing to the enhanced alpha-2-adrenoceptor activity. The lipolytic effect of noradrenaline increases gradually with age and attains the same effect as in adults within the 1st year of life. This phenomenon may be of importance for the regulation of lipolysis during early infancy. There is also a general increase in the lipolytic activity during the first year of life that seems related to fat cell growth.

\section{Acknowledgments}

The authors wish to thank Gunilla Micha-Johansson for her excellent technical assistance. The invaluable cooperation of the staff at the Department of Pediatric Anaesthesiology and Pediatric Surgery at St. Göran's Hospital is greatly appreciated. 
This study was supported by grants from the Swedish Medical Research Council (19x 01034), Karolinska Institute, the Samariten Foundation, the Osterman Foundation, the Swedish Society of Medicine, and the Foundation for Old Female Servants.

\section{References}

1. Häger, A., L. Sjöström, B. Arvidsson, P. Björntorp, and U. Smith. 1977. Body fat and adipose tissue cellularity in infants: a longitudinal study. Metab. Clin. Exp. 26:607-614.

2. Knittle, J. L., K. Timmers, and F. Ginsberg-Fellner. 1979. The growth of adipose tissue in children and adolescents. J. Clin. Invest. 63: 239-246.

3. Björntorp, P., and J. Östman. 1971. Human adipose tissue dynamics and regulation. Adv. Metab. Disord. 5:277-327.

4. Fain, J. N., and J. A. Garcia-Saintz. 1983. Adrenergic regulation of adipocyte metabolism. J. Lipid Res. 24:945-966.

5. Björkhem, I., P. Arner, A. Thore, and J. Östman. 1981. Sensitive kinetic bioluminescent assay of glycerol release from human fat cells. $J$. Lipid Res. 22:1143-1147.

6. Czeizel, A. 1980. Epidemiologic characteristics of congenital hernia. Helv. Pediatr. Acta. 35:57-60.

7. Rodbell, M. 1964. Metabolism of isolated fat cells: Effect of hormones on glucose metabolism and lipolysis. J. Biol. Chem. 239:375380.

8. Sjöström, L., P. Björntorp, J. Vrana. 1971. Microscopic fat cells: size measurements of frozen adipose tissue in comparison with automatic determinations of osimum-fixed fat cells. J. Lipid Res. 12:521-530.

9. Hirsch, J., and E. Gallian. 1968. Method for the determination of adipose cell size and cell number in man and animals. J. Lipid Res. 9: 110-119.

10. Zinder, Z., and B. Shapiro. 1971. Effect of cell size on epinephrineand ACTH-induced fatty acid release from isolated fat cells. J. Lipid Res. 12:91-95.

11. Engfeldt, P., P. Arner, H. Kimura, H. Wahrenberg, and J. Östman. 1983. Determination of adrenoceptors of the alpha-2-subtype on isolated human fat cells. Scand. J. Clin. Lab. Invest. 43:207-213.

12. Lafontan, M., and M. Berlan. 1982. Characterization of physiological agonist selectivity of human fat cell alpha-2-adrenoceptors: Adrenaline is the major stimulant of the alpha-2-adrenoceptors. Eur. $J$. Pharmacol. 82:107-111.

13. Engfeldt, P., P. Arner, H. Wahrenberg, and J. Östman. 1982. An assay for beta-adrenergic receptors in isolated human fat cells. J. Lipid Res. 23:715-719.

14. Engfeldt, P., P. Arner, and J. Östman. 1980. Influence of adipocyte isolation by collagenase on phosphodiesterase activity and lipolysis in man. J. Lipid Res. 21:443-448.

15. Johnston, F. E., M. Weston, S. Mc Kinney, J. Coleman, C. Pereira, and J. Rounds. 1984. Differences in the mean fat cell diameter of males between 1 and 48 months of age. Am. J. Phys. Anthropol. 65:341-345.

16. Roche, A. F. 1981. The adipocyte-number hypothesis. Child Dev. 52:31-43.

17. Östman, J., and S. Efendic. 1970. Catecholamines and metabolism of human adipose tissue. II. Effect of isopropyl-noradrenaline and adrenergic blocking agents on lipolysis in human adipose tissue in vitro. Acta. Med. Scand. 187:471-476.

18. Burns, W. T., and P. E. Langley. 1970. Lipolysis by human adipose tissue: the rate of cyclin $3^{\prime} 5^{\prime}$ adenosine, monophosphate and adrenergic receptor sites. J. Lab. Clin. Med. 75:983-987.

19. Frisk-Holmberg, M., and J. Östman. 1977. Differential inhibition of lipolysis in human adipose tissue by adrenergic beta-receptor blocking drugs. J. Pharmacol. Exp. Ther. 200:598-605.

20. Kather, H., E. Wieland, B. Fisher, A. Wirth, and G. Schlierf. 1985. Adrenergic regulation of lipolysis in abdominal adipocytes of obese subjects during caloric restriction: Reversal of catecholamine action caused by relief of endogenous inhibition. Eur. J. Clin. Invest. 15:3037.

21. Nyberg, G., A. Häger, and U. Smith. 1977. Effect of age on human adipose tissue metabolism and hormonal responsiveness. Acta. Paediatr. Scand. 66:495-500.

22. Novak, M., W. Melichar, and P. Hahn. 1966. Lipid metabolism in adipose tissue from human infants. Biol. Neonate 9:105-111.

23. Novak, M., and E. Monkus. 1972. Metabolism of subcutaneous adipose tissue in the immediate postnatal period of human newborns. Pediatr. Res. 6:73-80.

24. Persson, B., and R. Tunell. 1971. Influence of environmental temperature and acidosis on lipid mobilization in the human infant during the first two hours after birth. Acta. Paediatr. Scand. 61:385-389.

25. Hägnevik, K., G. Faxelius, L. Irestedt, H. Lagercrantz, B. Lundell, and B. Persson. 1984. Catecholamine surge and metabolic adaptation in the newborn after vaginal delivery and caesarean section. Acta. Paediatr. Scand. 73:602-609.

26. Lagercrantz, H., and P. Bistoletti. 1977. Catecholamine release in the newborn infant at birth. Pediat. Res. 11:889-893.

27. Hertel, J., N. J. Christensen, S. A. Pedersen, and C. Kühl. 1982. Plasma noradrenaline and adrenaline in infants of diabetic mothers at birth and at two hours of age. Acta. Paediatr. Scand. 71:941-945.

28. Hertel, J., C. Kühl, N. J. Christensen, and S. A. Pedersen. 1985. Plasma noradrenaline and adrenaline in newborn infants of diabetic mothers: Relation to plasma lipids. Acta. Paediatr. Scand. 74:521-524. 